\title{
Effects of carbamazepine on serum leptin, insulin levels and oxidative stress in epileptic patients
}

\author{
Imad A. Thanoon*, Othman A. Pachachi**, Mohammed M. Al-Sheikh*** \\ * Department of Pharmacology, *** Department of Medicine, College of Medicine, University of Mosul; \\ ** Department of Clinical Pharmacy, College of Pharmacy, University of Mosul.
}

(Ann. Coll. Med. Mosul 2012; 38 (1): 40-45).

Received: $19^{\text {th }}$ Jun. 2011; Accepted: $25^{\text {th }}$ Dec. 2011.

\begin{abstract}
Objectives: To assess the effect of carbamazepine (CBZ) monotherapy in male adult epileptic patients on serum leptin, insulin levels, body mass index and oxidative stress represented by serum malondialdehyde (MDA) in comparison to healthy controls.

Patients and methods: To achieve the aims of the current study, a case-control study design was adopted. A total of 38 male adult patients with primary generalized epilepsy, on continuous CBZ monotherapy, for at least six months before participation in the study, were collected over the period from Sept. 2010 to Jan. 2011. Forty apparently healthy male volunteers without previous history of epilepsy were recruited as controls. Fasting blood samples were taken and sera were separated and used to measure serum levels of leptin and insulin, and MDA. Body mass index (BMI) was calculated as weight in kilograms divided by the squared height in meters.
\end{abstract}

Results: The results of this study revealed that there was insignificant difference in BMI, serum leptin and insulin between male epileptic adult patients and their matched control subjects. The results also revealed that male epileptic adult patients had a significantly higher $(p<0.001)$ serum MDA compared to their matched control subjects.

Conclusion: Carbamazepine is a relatively low risky antiepileptic drug (AED) in terms of obesity, while it can cause oxidative stress as reflected by an elevated serum MDA in comparison to controls.

Keywords: Epileptic patients, carbamazepine, BMI, leptin, insulin, malondialdehyde

الأهداف: لتقييم تأثثير الكاربامز ابين كعلاج أحادي في مرضى الصرع من البالغين الذكور على مسنوى اللبتين و الأنسولين

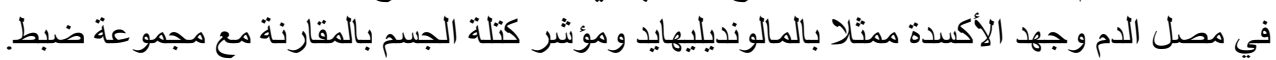

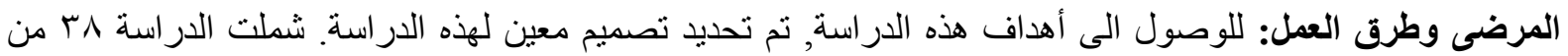

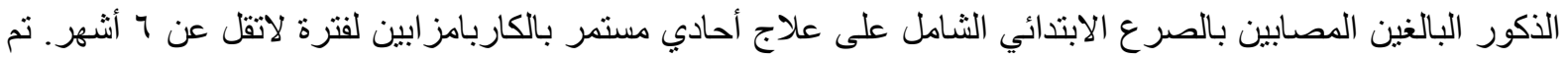

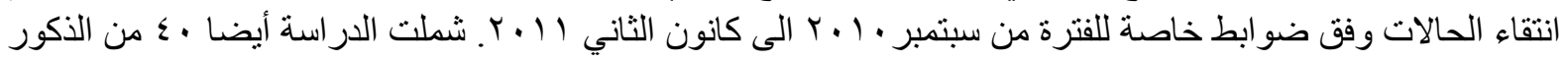

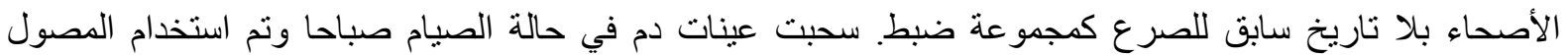

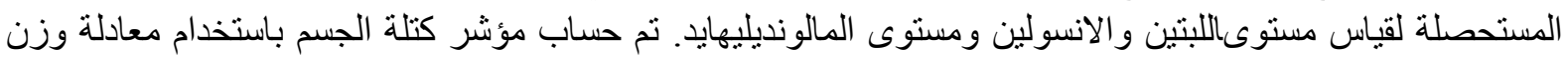

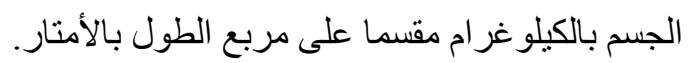

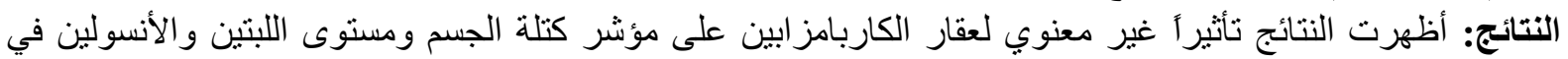

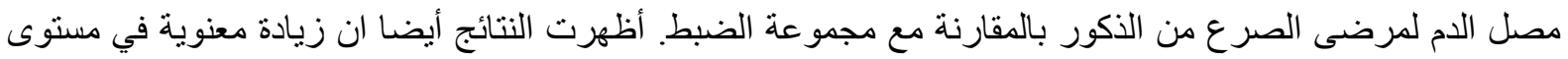




$$
\begin{aligned}
& \text { المالونديليهايد عند مرضى الصرع من الذكور المثبتين على الكاربامز ابين كعلاج أحادي مستمر بالمقارنة مع مجموعة } \\
& \text { الضبط. } \\
& \text { الاستتتاج: من الممكن الاستتتاج ان الكاربامزابين كعقار مضاد للصرع هو نوعا ما قليل المخاطر فيما يتعلق بزيادة الوزن } \\
& \text { وحالة المتلازمة الأيضية ولكن ممكن ان يسبب زيادة في جهد الأكسدة (متمثلا بزيادة مستوى المالونديليهايد في مصل الدم } \\
& \text { بالمقارنة مع مجمو عة الضبط). } \\
& \text { مفتاح الدلالة: مرضى الصرع, الكاربامز ابين, دلالة كتلة الجسم, اللبتين, الأنسولين, المالونديليهايد. }
\end{aligned}
$$

$\mathrm{M}$ any types of endocrine and metabolic dysfunctions are associated with epilepsy and its medications that may impair individual's overall function. ${ }^{(1,2)}$ Epilepsy and its medications are associated with weight changes in which weight gain is the most common and distressing problem. ${ }^{(3)}$ Weight gain is a difficult problem at any age, particularly in adolescence, a period of increased awareness to body weight and image. ${ }^{(4)}$ Weight gain not only affects body image and self-confidence with adverse psychological effects leading to noncompliance to medications, ${ }^{(5)}$ but also associated with pathologic consequences related to obesity as dyslipidemia, hypertension, diabetes mellitus and atherosclerosis with its related vascular complications. ${ }^{(6)}$ Epilepsy and antiepileptic drugs(AEDs) may alter weight homeostasis regulating process including the two main homeostatic hormones, leptin and insulin. Increased blood levels of leptin and insulin due to leptin and insulin resistances are observed in patients with epilepsy. ${ }^{(7,8)}$

Leptin controls weight homeostasis through two main neuropeptidergic systems that both project into the arcuate nucleus, neuropeptide $\mathrm{Y}(\mathrm{NPY})$ and pro-opiomelanocortin (POMC) expressing neurons. ${ }^{(9,10)}$ These neurons exert two opposite functions. NPY expressing neurons are anabolic, upon stimulation, food intake and metabolic efficiency are increased while energy expenditure is decreased. In contrast, the counterpart POMC expressing neurons are catabolic, upon stimulation, food intake and metabolic efficiency are decreased while energy expenditure is increased. ${ }^{(11)}$

It has been reported that increased generation of free radicals or decreased activity of antioxidant defense systems can cause some forms of seizures and in addition can increase the risk of seizure recurrence. ${ }^{(12,13)}$ Many AEDs are metabolized to generate reactive metabolites with the capability of covalent binding to macromolecules as proteins or other vital biomolecules and hence eliciting systemic toxicity. ${ }^{(13,14)}$ Lipid peroxidation caused by increased generation of free radicals or decreased activity of antioxidant defense systems have been suggested to be critically involved in seizure control. ${ }^{(12)}$ The aims of this study are to assess the effect of CBZ monotherapy in male epileptic patients on BMI, serum leptin, insulin and MDA levels (as a representative of oxidative stress), in comparison with healthy controls.

\section{Patients and methods}

\section{A. Epileptic patients}

This study included 38 male adult patients with primary generalized epilepsy, on continuous carbamazepine (CBZ) (Tegretol) [Novartis, Switzerland] monotherapy, for at least six months before participation in the study. These patients were referred from the private clinic of a consultant neurologist over the period from Sept. 2010 to Jan. 2011. Patients with the following criteria were excluded from this study:

1. Patients with secondary epilepsy.

2. Patients with other neurological, medical, or psychiatric disorders.

3. Patients with rapidly progressive disorders that could alter their weight.

4. Patients with family history of body weight disorders.

5. Patients treated with other AEDs beside CBZ. 
6. Patients treated with $\mathrm{CBZ}$ for less than six months.

Approval to conduct this study was obtained from the ethical committee of the Local Health Authority in Mosul City and from the College of Medicine-University of Mosul. Blood samples were taken from them and assay of serum leptin, MDA and insulin levels were done.

\section{B. Control subjects}

Forty apparently healthy male volunteers without previous history of epilepsy were recruited as controls with age matching to the patients group. The control group was judged free of any illness by history and clinical examination. They were included in the study to compare the normal values for serum leptin, insulin and MDA levels.

\section{Specimen collection and analysis}

Samples from the control (friends and relatives) and the patients were collected and assay of serum levels of leptin, insulin, MDA and TAS were done as in the patients group. Serum leptin was measured by enzyme linked immunosorbent assay (ELISA) technique, using the IBL leptin ELISA Kit (Germany), which is an immunoassay for the quantitative in vitro diagnostic measurment of leptin in serum and plasma. Serum insulin was also measured by ELISA kit (DRG-Germany). Serum MDA levels were measured using TBA assay method. ${ }^{(15)}$ Body mass index (BMI) was calculated using the following equation:

$\mathrm{BMI}=$ Weight $(\mathrm{Kg}) /$ Height $\left(\mathrm{m}^{2}\right)^{(16)}$.

\section{Statistical analysis}

The data obtained in the current study were analyzed using Statistical Package for Social Sciences (SPSS) (version 16). Standard statistical methods were used to determine the mean and standard deviation. Unpaired t-test was used to compare the results of different biochemical parameters of epileptic adult patients with their matched controls.

\section{Results}

Table (1) and (2) demonstrated the demographic characteristics of the male epileptic adult patients and their matched control subjects respectively.
Table (3) demonstrated the comparison of $B M I$, serum levels of leptin, insulin and MDA between male epileptic adult patients receiving continuous CBZ monotherapy and their matched control subjects.

The results of this study revealed that there was insignificant difference in BMI, serum leptin and insulin between male epileptic adult patients receiving continuous CBZ monotherapy and their matched control subjects. The results also revealed that male epileptic adult patients on continuous CBZ monotherapy had a significantly higher $(p<0.001)$ serum MDA compared to their matched control subjects.

Table (1): The characteristics of the male epileptic adult patients.

\begin{tabular}{|l|c|}
\hline \multicolumn{1}{|c|}{ Parameters } & $\begin{array}{c}\text { Mean } \pm \text { SD } \\
\text { Number=38 }\end{array}$ \\
\hline Patients age (years) & $29.54 \pm 5.36$ \\
\hline Body mass index (BMI) $\left(\mathrm{kg} / \mathrm{m}^{2}\right)$ & $24.59 \pm 2.92$ \\
\hline Duration of illness (years) & $3.25 \pm 2.05$ \\
\hline Duration of using CBZ (months) & $25.09 \pm 20.08$ \\
\hline Dose of CBZ (mg/day) & $590.90 \pm 144.44$ \\
\hline
\end{tabular}

Table (2): The characteristics of the control adult subjects.

\begin{tabular}{|l|c|}
\hline \multicolumn{1}{|c|}{ Parameters } & $\begin{array}{c}\text { Mean } \pm \text { SD } \\
\text { Number }=40\end{array}$ \\
\hline Subjects age (years) & $30.05 \pm 5.95$ \\
\hline BMI $\left(\mathrm{kg} / \mathrm{m}^{2}\right)$ & $23.33 \pm 1.91$ \\
\hline
\end{tabular}

Table (3): BMI and serum levels of leptin and malondialdehyde (MDA) in the male epileptic patients and their matched control subjects.

\begin{tabular}{|l|c|c|c|}
\hline \multicolumn{1}{|c|}{ Parameters } & $\begin{array}{c}\text { Epileptic } \\
\text { patients }\end{array}$ & $\begin{array}{c}\text { Control } \\
\text { subjects }\end{array}$ & $\begin{array}{c}\mathrm{P} \\
\text { Value }\end{array}$ \\
\hline $\begin{array}{l}\mathrm{BMI}\left(\mathrm{kg} / \mathrm{m}^{2}\right) \\
\text { Mean } \pm \mathrm{SD}\end{array}$ & $24.59 \pm 2.92$ & $23.33 \pm 1.91$ & $\mathrm{NS}$ \\
\hline $\begin{array}{l}\text { Leptin }(\mathrm{ng} / \mathrm{ml}) \\
\text { Mean } \pm \mathrm{SD}\end{array}$ & $4.60 \pm 1.20$ & $3.91 \pm 1.96$ & $\mathrm{NS}$ \\
\hline $\begin{array}{l}\text { MDA }(\mu \mathrm{Mol} / \mathrm{L}) \\
\text { Mean } \pm \mathrm{SD}\end{array}$ & $1.88 \pm 0.19$ & $0.95 \pm 0.22$ & $<0.001$ \\
\hline Insulin $(\mathrm{mU} / \mathrm{L})$ & $8.37 \pm 7.2$ & $8.56 \pm 7.00$ & $\mathrm{NS}$ \\
\hline
\end{tabular}

NS: statistically non-significant 


\section{Discussion}

Epilepsy is a common chronic neurological problem. Its treatment is often for years or even lifelong. ${ }^{(17)}$ It should be noted that patients with epilepsy may manifest metabolic adverse effects throughout the course of their management with anti-epileptic drugs (AEDs), which on long-term may impair individual's overall function. ${ }^{(18)}$ Clinically significant weight gain has been reported with several AEDs including the conventional agents valproate (VPA), CBZ and the newer medications gabapentin and vigabatrin and may result in lack of compliance with or even discontinuation of therapy. ${ }^{(19)}$ Numerous studies reported weight gain with VPA in up to $50-70 \%$ of the patients. ${ }^{(3,20,21)}$ Its etiology is most likely multi-factorial and controversial. Weight gain appears to be less a problem with CBZ than with VPA. The proposed mechanism of CBZ-associated weight gain can arise from edema but has also been associated with increased appetite and food consumption in the absence of edema. ${ }^{(22)}$ The CBZ-induced edema has been postulated to be caused by drug-induced alterations in the secretion of antidiuretic hormone(ADH), although studies only inconsistently show an effect of the drug on plasma ADH levels. ${ }^{(23)}$

Our study revealed insignificant effect of $C B Z$ on BMI which is consistent with the studies of Biton, ${ }^{(24)}$ and Uludag et al ${ }^{(25)}$ but inconsistent with the studies of Richens et $a^{(26)}$ and Hogan et al. ${ }^{(27)}$ They reported that between $15 \%$ and $25 \%$ of patients treated with CBZ developed weight gain. The two common homeostatic hormones, insulin and leptin have been expected to form a common link to weight gain in epilepsy with the use of some AEDs.

Our study also revealed insignificant effect of CBZ on serum leptin level and insulin. Rauchenzauner et al, ${ }^{(28)}$ compared two patient groups that use VPA and non-VPA AEDs regarding serum leptin and insulin levels. They concluded that non-VPA AEDs, (lamotrigine and oxcarbazepin) were thought to have no effect on leptin and insulin levels. There are a few studies such as ours that evaluate effect of CBZ treatment directly on serum leptin and insulin levels. Our findings are consistant with the results of Uludag etal and Hamed et al. ${ }^{(25,29)}$

Our study reported an elevated serum MDA level in epileptic male patients on CBZ therapy in comparison with healthy controls. Our findings are consistent with the results of the study conducted by Aycicek and Iscan. ${ }^{(30)}$ They reported a markedly increased serum total peroxide levels in CBZ treated and untreated epileptic patients compared to healthy controls. Solowiej and Sobaniec ${ }^{(31)}$ on studying the effect of CBZ and VPA therapy on antioxidant enzyme activity and serum lipid peroxidation in young epileptic patients, concluded that MDA concentration was elevated in all epileptic patients, significantly both in VPA monotherapy and in polytherapy, while insignificantly in newly diagnosed epileptics and in CBZ monotherapy. In agreement with our findings the study conducted by Nemade et al. ${ }^{(32)}$ They reported that epileptic patients on regular or irregular treatment (phenytoin and CBZ), have an increased serum MDA levels compared to healthy controls. On going with our findings, the two year prospective study conducted by Yuksel et $a l,{ }^{(33)}$ they concluded from studying changes in the antioxidant system in epileptic children receiving antiepileptic drugs, that during CBZ therapy, lipid peroxidation levels increased when compared with the control group. On the other hand Liu et $a{ }^{(34)}$, reported no significant differences in lipid peroxidation in epileptic children on CBZ therapy compared with the controls.

In conclusion CBZ monotherapy can be regarded as a safe drug with regard to $\mathrm{BMI}$, serum leptin and insulin levels, but it can cause oxidative stress as represented by elevated serum MDA levels.

\section{References}

1. Hamed SA, Nabeshima T. The high atherosclerotic risk among epileptics: the atheroprotective role of multivitamins. Jap J Pharmacol Sci 2005; 98 (4): 340-353.

2. Hamed SA, Hamed EA, Kandil MR, ElShereef HK, Abdellah MM, Omar $\mathrm{H}$. Serum thyroid hormone balance and lipid profile in patients with epilepsy. Epilepsy Res 2005; 66: 173-183. 
3. Verrotti $A$, Basciani $F$, De Simone $M$, Trotta D, Morgese G, Chiarelli F. Insulin resistance in epileptic girls who gain weight after therapy with valproic acid. $\mathrm{J}$ Child Neurol 2002; 17: 265-268.

4. Sheth R. Adolescent issues in epilepsy. J Child Neurol 2002; 17 (Suppl I2): S23-S27.

5. Kawachi I. Physical and psychological consequences of weight gain. J Clin Psych 1999; 60: 5-9.

6. McTigue K, Larson JC, Valoski A, Burke G, Kotchen J, Lewis CE, et al. Mortality, cardiac and vascular outcomes in extremely obesitive women. JAMA 2006; 296(1): 79-86.

7. Lagace DC, Mcleod RS, Nachtigal MW. Valproic acid inhibits leptin secretion and reduces leptin messenger ribonucleic acid levels in adipocytes. Endocrinol 2004; 145 (12): 5493-5503.

8. Aydin K, Serdaroglu A, Okuyaz C, Bidect S, Gucuyener K. Serum insulin, leptin, and neuropeptide $Y$ levels in epileptic children treated with Sodium Valproate. J Child Neurol 2005; 20: 848-851.

9. Cowley MA, Smart JL, Rubenstein M, Cerdan MC, Diano S, Horvath TL, et al. Leptin activates anorexigenic POMC neurons through a neural network in the arcuate nucleus. Nature 2001; 411: 480484.

10. Niswender KD, Morrison CD, Clegg DJ, Olson R, Baskin DG, Myers Jr, et al. Insulin activation of phosphatidylinositol 3kinase in the hypothalamic arcuate nucleus: a key mediator of insulin-induced anorexia. Diabetes 2003; 52: 227-231.

11. Kim MS, Pak YK, Jang PG, Namkoong C, Choi YS, Won JC, et al. Role of hypothalamic Foxo1 in the regulation of food intake and energy homeostasis. Nature Neurosci 2006; 9 (7): 901-906.

12. Maertens $P$, Dyken $P$, Graf W, Pippenger C, Chronister R, Shah A. Free radicals, anticonvulsants and the neuronal ceroid lipofuscinosis. Am J Med Genetics 1995; 57: 225-228.

13. Yuksel A, Cengiz M, Seven M, Ulutin T. Erythrocyte glutathione, glutathione peroxidase, superoxide dismutase and serum lipid peroxidation in epileptic children with Sodium Valproate and carbamzepine monotherapy. J Basic Clin Pharmacol 2000; 11: 73-81.

14. Niketic V, Ristic S, Saicic ZS, Spasic M, Buzadzic B, Stojkovic M. Activities of antioxidant enzymes and formation of the glutathione adduct of hemoglobin $(\mathrm{Hb}$ ASSG) in epileptic patients with long-term antiepileptic therapy. Farmaco 1995; 50: 811-813.

15. Buege JA, Aust SD. Thiobarbaturic acid assay. Methods Enzymol 1978; 52: 306307.

16. Leermarkers EA, Dunn AL, Blair SN. Exercise management of obesity. Med Clin North America 2000;84:419-425.

17. Hauser WA. Incidence and Prevalance. In: Engel J; Pedley TA (Eds). Epilepsy: A comprehensive Textbook. LippincottRaven. Philadelphia, 2008. pp:47-57.

18. Sheth RD. Metabolic concerns associated with antiepileptic medications. Neurol 2004; 63 (suppl 4):S 24-29.

19. Jallon P, Picard F. Body weight gain and anticonvulsants: a comparative review. Drug Saf 2001;24: 969-978.

20. Corman $\mathrm{CL}$, Leung NM, Guberman $\mathrm{AH}$. Weight gain in epileptic patients during treatment with valproic acid: a retrospective study. Can J Neurol Sci 1997; 24: 240-244.

21. Isojärvi JIT, Tauboll E, Tapanainen JS, Pakarinen $\mathrm{AJ}$, Laatikainen $\mathrm{TJ}$, Knip $\mathrm{M}$, et al. The association between Sodium Valproate and polycystic ovary syndrome: a response and an alternative view. Epilepsia 2001; 42: 305-310.

22. Lampl Y, Eshel Y, Rapaport A, SarovaPinhas I. Weight gain, increased appetite and excessive food intake induced by carbamazepine. Clin Neuropharmacol 1991;14: 251-255.

23. Meinders AE,Cejka V, Robertson G. The antidiuretic action of Carbamazepine in man. Clin Sci Mol Med 1974;47:289-299.

24. Biton V. Effect of antiepileptic drugs on body weight: Overview and clinical implication for the treatment of epilepsy. CNS Drugs 2003;17(11):781-791. 
25. Uludag IF, Kulu U, Sener U, Kose S, Zorlu $Y$. The effect of carbamazepine on serum leptin levels. Epilepsy Res 2009;86(1): 4853.

26. Richens A, Davidson DL, Cartlidge NE, Easter DJ. A multicentre comparative trial of sodium valproate and carbamazepine in adult onset epilepsy. Adult EPITEG Collaborative Group. J Neur Neurosurg Psychiatry 1994;57:682-687.

27. Hogan RE, Bertrand ME, Deaton RL, Sommerville KW. Total percentage body weight changes during add-on therapy with tiagabine, carbamazepine and phenytoin. Epilepsy Res 2000;41:23-28.

28. Rauchenzauner M, Haberlendt E, SchollBurgi S, Karall D, Schoenherr E. Effect of valproic acid treatment on body composition, leptin and the soluble leptin receptor in epileptic children. Epilepsy Res 2008;80:142-149.

29. Hamid SA, Fida NM, Hamed EA. States of serum leptin and insulin in children with epilepsy: risk predictors of weight gain.Eur J Paediatr Neurol 2009;13(3):261-268.
30. Aycicek A, Iscan A. The effects of carbamazepine, valproic acid and Phenobarbital on the oxidative and antioxidative balance in epileptic children. Eur Neurol 2007;57(2):65-69.

31. Solowiej E, Sobaniec W. The effect of antiepileptic drug therapy on antioxidant enzyme activity and serum lipid peroxidation in young patients with epilepsy. Neurol Neurochir Pol 2003; 37(5): 991-1003.

32. Nemade ST, Melinkeri RR. Effect of antiepileptic drugs on antioxidant status in epilepsy. Current Neurobiol 2010;1(2):1-7.

33. Yuksel A, Cengiz M, Seven M, Ulutin T. Changes in the antioxidant system in epileptic children receiving antiepileptic drugs: Two-year prospective studies. J Child Neurol 2001;16:603-606.

34. Liu CS, Wu HM, Kao SH, Wei YH. Serum trace elements, glutathione, copper/zinc superoxide dismutase and lipid peroxidation in epileptic patients with phenytoin or carbamazepine monotherapy. Clin Neuropharmacol 1998; 21(1):62-64. 